\title{
Correction to: Neotropical Diversification: Patterns and Processes
}

\author{
Valentí Rull and Ana Carolina Carnaval
}

\section{Correction to:}

V. Rull, A. C. Carnaval (eds.), Neotropical Diversification:

Patterns and Processes, Fascinating Life Sciences https://doi.org/10.1007/978-3-030-31167-4

The original version of the book was inadvertently published with an incorrect fore name of the author in chapters 10 and 11 as C. Camila Ribas. The name has been now corrected as Camila C. Ribas. 